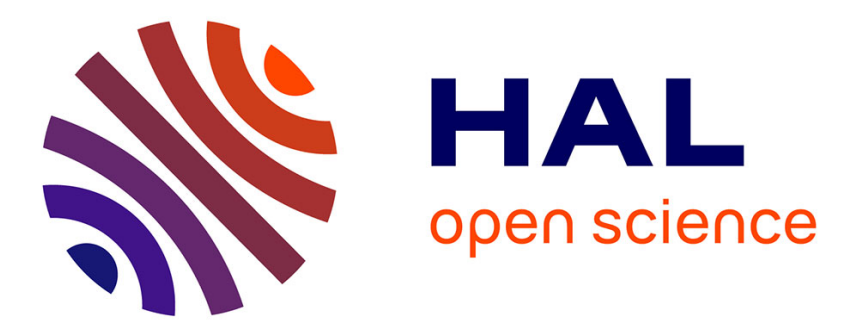

\title{
Identifying priority conservation areas for a recovering brown bear population in Greece using citizen science data
}

\author{
A -s Bonnet-lebrun, Alexandros A Karamanlidis, M de Gabriel Hernando, I \\ Renner, O Gimenez
}

\section{To cite this version:}

A -s Bonnet-lebrun, Alexandros A Karamanlidis, M de Gabriel Hernando, I Renner, O Gimenez. Identifying priority conservation areas for a recovering brown bear population in Greece using citizen science data. Animal Conservation, 2019, 23, pp.83 - 93. 10.1111/acv.12522 . hal-03502430

\section{HAL Id: hal-03502430 \\ https://hal.science/hal-03502430}

Submitted on 25 Dec 2021

HAL is a multi-disciplinary open access archive for the deposit and dissemination of scientific research documents, whether they are published or not. The documents may come from teaching and research institutions in France or abroad, or from public or private research centers.
L'archive ouverte pluridisciplinaire HAL, est destinée au dépôt et à la diffusion de documents scientifiques de niveau recherche, publiés ou non, émanant des établissements d'enseignement et de recherche français ou étrangers, des laboratoires publics ou privés. 
Title: Identifying priority conservation areas for a recovering brown bear population in

2 Greece using citizen science data

4 A-S. Bonnet-Lebrun ${ }^{1, \#}$, A.A. Karamanlidis ${ }^{2,3,}{ }^{*}$, M. de Gabriel Hernando ${ }^{2,4}$, I. Renner ${ }^{5}$, O. $5 \quad$ Gimenez $^{1}$

${ }^{1}$ CEFE, CNRS, Université of Montpellier, Université Paul Valéry Montpellier 3, EPHE, IRD, Montpellier, France

${ }^{2}$ ARCTUROS, Civil Society for the Protection and Management of Wildlife and the Natural Environment, 53075 Aetos, Florina, Greece

${ }^{3}$ Faculty of Environmental Sciences and Natural Resource Management, Norwegian

University of Life Sciences, 1432 Ås, Norway

${ }^{4}$ Department of Biodiversity and Environmental Management, Faculty of Biological and Environmental Sciences, Universidad de León, 24007 León, Spain

${ }^{5}$ School of Mathematical and Physical Sciences, The University of Newcastle, University Drive, Callaghan, NSW2308, Australia

${ }^{\#}$ A-S. Bonnet-Lebrun and A.A. Karamanlidis contributed equally to this study.

${ }^{*}$ Corresponding author

\section{Running head: Identifying priority conservation areas for bears}

Abstract: Understanding the processes related to wildlife recoveries is not only essential in solving human-wildlife conflicts, but also for identifying priority conservation areas and in turn, for effective conservation planning. We used data from a citizen science program to study spatial aspects related to the demographic and genetic recovery of brown bears in Greece and to identify new areas for their conservation. We visually compared our data with an estimation of the past distribution of brown bears in Greece and used a point process approach to model habitat suitability, and then compared our results with the current distribution of brown bear records and with that of protected areas. Our results indicate that in the last 15 years bears have increased their range by as much as $100 \%$, by occupying 
1 mainly anthropogenic landscapes and areas with suitable habitat that are currently not

2 legally protected, thus creating a new conservation reality for the species in Greece. This

3 development dictates the re-evaluation of the national management and conservation

4 priorities for brown bears in Greece by focusing in establishing new protected areas that will

5 safeguard their recovery. Our conservation approach is a swift and cheap way of identifying

6 priority conservation areas, while gaining important insights on spatial aspects of population

7 recovery. It will help prioritize conservation actions for brown bears in Greece and may serve

8 as a model conservation approach to countries facing similar financial and logistic constraints

9 in the monitoring of local biodiversity or facing challenges in managing rapid population

10 recoveries. Our conservation approach appeared also to be better suited to identifying

11 priority areas for conservation in areas with recovering wildlife populations and may

therefore be used as an "early-warning" conservation system.

14 Keywords: Greece, large carnivores, Poisson point process, presence-only data, Ursus arctos 
2 Large carnivores have been celebrating significant population comebacks in Europe (Chapron

3 et al., 2014), sparking an increased interest in identifying the preconditions, factors and

4 processes that have facilitated these comebacks (e.g. López-Bao et al., 2015). A thorough understanding of the processes related to large carnivore recoveries is not only essential in solving the increasing number of human-large carnivore conflicts (Bautista et al., 2016), but

7 also for predicting potential habitat in areas of large carnivore population recovery and in

8 turn, for effective conservation planning in the European context of human-dominated 9 landscapes (Linnell et al., 2008). At the same time, the vulnerability to human threats (Ripple et al., 2014), the socio-cultural and financial implications of human-wildlife conflicts (Treves \& Karanth, 2003) and the often large spatial requirements (Ripple et al., 2014, Newsome \& Ripple, 2015) and long dispersal abilities (Kojola et al., 2006) of large carnivores dictate a management and conservation approach that is based on the swift collection and evaluation of accurate data on their status. This ensures their recovery and survival through their adequate representation inside and outside protected areas (Di Minin et al., 2016).

As new technologies emerge that make it easier to collect and transmit information on one's location, volunteer participation in data collection is becoming increasingly more important as an ecological research tool (Dickinson et al., 2012). Volunteers participating in citizen science programs can collect more data and cover wider areas, faster than researchers alone would, all of this at a lower cost (Dickinson et al., 2010, Dickinson et al., 2012). If analysed properly, opportunistic, presence-only data of citizen science projects can produce reliable estimates of wildlife distribution trends (van Strien et al., 2013); however, such data may suffer from observer bias [sensu Warton et al. (2013), also commonly referred 
ecological variables are variables that are likely to influence a species' occurrence, whereas

2

observer bias variables are variables that are likely to influence the detection of a species (the observer's occurrence mainly). When making predictions, only the ecological variables are used, and a common value for the observer bias variables (e.g. the average, or the minimum/maximum value) is set, making the predictions as if the distribution of observers was spatially homogeneous. This method has been successfully applied to model the distribution of plant data (Warton et al., 2013), but is yet to be applied to animals.

Presence-only data obtained from citizen science programs are particularly relevant to large carnivores, such as brown bears (Ursus arctos), because bears are difficult to monitor, due to their cryptic and solitary nature and due to their relatively low density of occurrence over large areas (Kindberg et al., 2009). At the same time however, bears are also highly charismatic species attracting public attention, increasing the chances that observations would be reported, thus making them particularly suitable for citizen science programs.

Brown bears are globally considered by the IUCN as species of Least Concern. They are the only Ursid in Europe, where several populations are small, isolated and threatened by habitat loss and fragmentation and by human-bear conflicts (Swenson \& Sandegren, 2000, Bautista et al., 2016, Piédallu et al., 2017). This is particularly the case for brown bears in Greece where the species reaches its southernmost European distribution and is considered to be endangered, numbering fewer than 500 individuals (Karamanlidis et al., 2015). Despite increasing human-wildlife conflicts (Karamanlidis et al., 2011), bears have been recovering in recent years (i.e. after approximately the year 2000) in Greece, both demographically (Karamanlidis et al., 2015) and genetically (Karamanlidis et al., 2018). At the same time, circumstantial evidence suggests that the species has also been expanding its range (Karamanlidis et al., 2008); however, no thorough, nation-wide study has been conducted so far to substantiate this fact, partially because of the logistic and financial constraints that have befallen the country since the onset in 2009 of a financial crisis. This incomplete understanding of the current distribution of brown bears in Greece is hindering their effective conservation, which in turn may compromise the ongoing demographic and genetic recovery of the species in the country.

The aims of this study were to take advantage of a large citizen science data set to study the presence of brown bears in Greece during the recovery of their population in the country 
and to identify new priority areas for their conservation. The first aim was achieved by visually comparing our citizen science data with an estimation of the past distribution of the species in the country. The latter aim was achieved by applying Warton et al.'s (2013) approach to our citizen science data to model habitat suitability, and then comparing the predictions of our model with the current distribution of brown bear records in Greece and with that of protected areas in the country. This comparison allowed us to assess the distribution of highly suitable bear habitat in relation to the distribution of bears and protected areas and obtain new, valuable insights on the spatial recovery and conservation priorities of brown bears in Greece.

\section{Materials and methods}

\section{Data collection}

Data on bear presence were collected from 2004-2016 within the framework of a citizen science program, the "Hellenic Brown Bear Rescue and Information Network" (HBBRIN), established by the non-governmental organization ARCTUROS. Information on bear presence (i.e. opportunistic observations, damage to human property, attacks to humans, approaches to inhabited areas) was received from throughout the range of the species in the country (i.e. the Pindos Mountains in the western part and the Rodopi Mountains in the eastern part of Greece) through the post, telephone or email and was verified either on site by a field team or through the evaluation of the information provided (e.g. photographs and videos).

\section{Studying brown bear presence in Greece}

To gain insights on spatial aspects of the demographic and genetic recovery of brown bears in Greece, we mapped bear records from the HBBRIN using QGIS v2.14 (QGIS Development Team, 2016) and visually compared them with the past distribution of the species in the country. We considered as a reference the distribution of brown bears in Greece (Fig. 1) published in the assessment of the species for the Red Book of Endangered Species of Greece (Mertzanis et al., 2009). In this assessment the total area of continuous brown bear range in Greece was estimated at approximately 13,500 $\mathrm{km}^{2}$, which consisted of two geographically distinct population nuclei in the northeastern and northwestern part of the country. Although no information is available on how this map has been produced and whether it represents only core areas of the species or also areas of temporal re-occurrence, it is evident, from the references therein and its publication date, that the map is the best 
available account on the distribution of brown bears in Greece prior to their demographic and genetic recovery (i.e. estimated to have started at the beginning of the century) and the beginning of our study.

To compare the habitat characteristics between the past distribution of brown bears in Greece and the new areas where the species was documented through the HBBRIN, we calculated the percentage of coverage of different habitat types [extracted from Corine Land Cover 2006 (CLC) seamless vector data, Version 16 (European Commission, 04/2012)], road density (OpenStreetMap, 2016) and human population density (Center for International Earth Science Information Network (CIESIN) \& Centro Internacional de Agricultura Tropical (CIAT), 2005). The size of the area where the species was documented through the HBBRIN was calculated by Local Convex Hulls (LoCoHs) using a fixed radius of $50 \mathrm{~km}$ and the five nearest neighbors of each point [R package "rhr"; (Signer, 2016)], excluding however 5\% of the outermost records in order to reduce the impact of extreme observations.

\section{Identifying new priority areas for brown bear conservation in Greece}

\section{Modelling framework}

We modelled the intensity of observations per space unit as our response variable in an inhomogeneous Point Process Model (PPM), a common tool for modelling the occurrence of species based on a set of explanatory factors using presence-only data (Renner et al., 2015; Appendix 1). Inhomogeneous PPMs take as input the observed point locations and a set of spatially-indexed predictors, and produce as output an intensity of point locations per unit area. This is achieved by introducing a set of quadrature points (often spaced along a rectangular grid) at which the predictors are also measured. We divided these spatial predictors into two categories: (1) ecological variables, or variables that affect the probability of presence of the species in the area, and (2) observer bias variables, affecting the probability of the species to be detected given that it is present in the area. Here we compared two approaches: (1) a simple approach, where only ecological variables were taken into account, and (2) the method by Warton et al. (2013), where both ecological and observer bias variables were taken into account when building the model, and predictions were made by setting the observer bias variables to a common value for the whole study region (a process thereafter called "correction for observer bias"; Appendix 1). By correcting for observer bias, the output is detrended and hence can be interpreted as an intensity of 
bear observations per square kilometre, if all locations in the study area had equal sampling effort as quantified by the observer bias variables (Warton et al., 2013). If we can accept that the realised distribution of brown bears in Greece is compatible with preferred habitat, then such maps of corrected intensity are proportional to habitat suitability.

To account for spatial dependence among point locations, we fitted a special type of PPM called an "area-interaction model", which assumes interactions among all points within a $2 \mathrm{~km}$ radius (see Appendix 1). Fitting an area-interaction model can be thought of as being analogous to accounting for over-dispersion in Poisson count data. The area-interaction model introduces a point interaction covariate which captures additional spatial patterns not explained by the other predictors, the same way that an over-dispersion parameter captures excessive variance not accounted for by the other predictors in a Poisson regression. We considered the fitted area-interaction model as our best model and therefore only present parameter estimates for this model - a comparison with other considered models is presented in Appendix 1.

\section{Explanatory variable selection}

A grid of $1 \times 1 \mathrm{~km}^{2}$ was laid over the study area, which corresponds to the resolution of the coarsest explanatory variable. The mean value of a set of explanatory variables expected to influence either bear or observer presence was calculated for each grid cell. Explanatory variables were chosen following previous brown bear studies in Europe (Naves et al., 2003, Martin et al., 2013). We used topography (i.e. maximum altitude and mean slope), distance to forest edge and distance to shrubland edge, density of rivers (i.e. accumulated length of rivers in the pixel), and percentage of agricultural land as ecological variables, and distance to human settlements, as well as distance to the closest primary or secondary road as observer bias variables (Appendix 1, Table S1). The construction of the grid and the calculation and extraction of the ecological variables were done in the $R$ software $(R$ Development Core Team, 2011) and in QGIS (Quantum GIS Development Team, 2013).

Variable selection was done using a LASSO regularization path (Appendix 1). A model fitted with a LASSO penalty can shrink some parameter estimates to be exactly zero, effectively reducing the number of corresponding explanatory variables in the model. We fitted an entire regularization path of models with increasing penalties and chose the model which minimized BIC. We first assessed the effect of each covariate on the intensity of brown 
bears per square kilometre as estimated in the PPM. To visualise these effects, we produced scatterplots of the predicted intensities vs. standardised covariates, and then fitted a smoothed generalized additive model to produce a response curve.

Comparison of habitat suitability predictions with bear records and protected area distribution in Greece

The Natura 2000 (N2K) network is a European network of protected areas for birds and habitats (http://ec.europa.eu/environment/nature/natura2000/db gis/index en.htm). Some of the sites in the N2K network (33 out of 419) comprise a dedicated network for the protection of bears in Greece [as reported in their Standard Data Forms (SDFs)]. To compare our habitat suitability predictions with the presence of bears and the distribution of protected areas in Greece, we mapped all the N2K sites in Greece (http://www.ekby.gr/ekby/en/Natura2000 main en.html; last updated in 2012), identified the sites included in the dedicated network for the protection of bears in Greece and those which were not. For this, we mapped only areas of highly suitable habitat, defined as those grid cells with predicted intensities above the $80 \%$ quantile. Only N2K sites with more than $5 \%$ of their total area classified as highly suitable habitat were retained. Areas containing highly suitable habitat, but not included in the N2K network of protected areas, were also identified.

\section{Results}

\section{Studying brown bear presence in Greece}

From 2004 - 2016 the HBBRIN recorded the presence of bears (Appendix S2, Table Bear_spxy2017) on 632 occasions: $40 \%$ of these cases (i.e. 251 data points) were located within the past distribution of the species, $60 \%$ beyond (Fig. 1). The new distribution area of brown bears in Greece that was not included in the map of Mertzanis et al. (2009) covered a total of $16,661 \mathrm{~km}^{2}$ and was, compared to the past distribution of the species, characterized by lower elevations, higher coverage by primary and secondary roads and agricultural areas and lower coverage by mature forests (Table 1 ). 


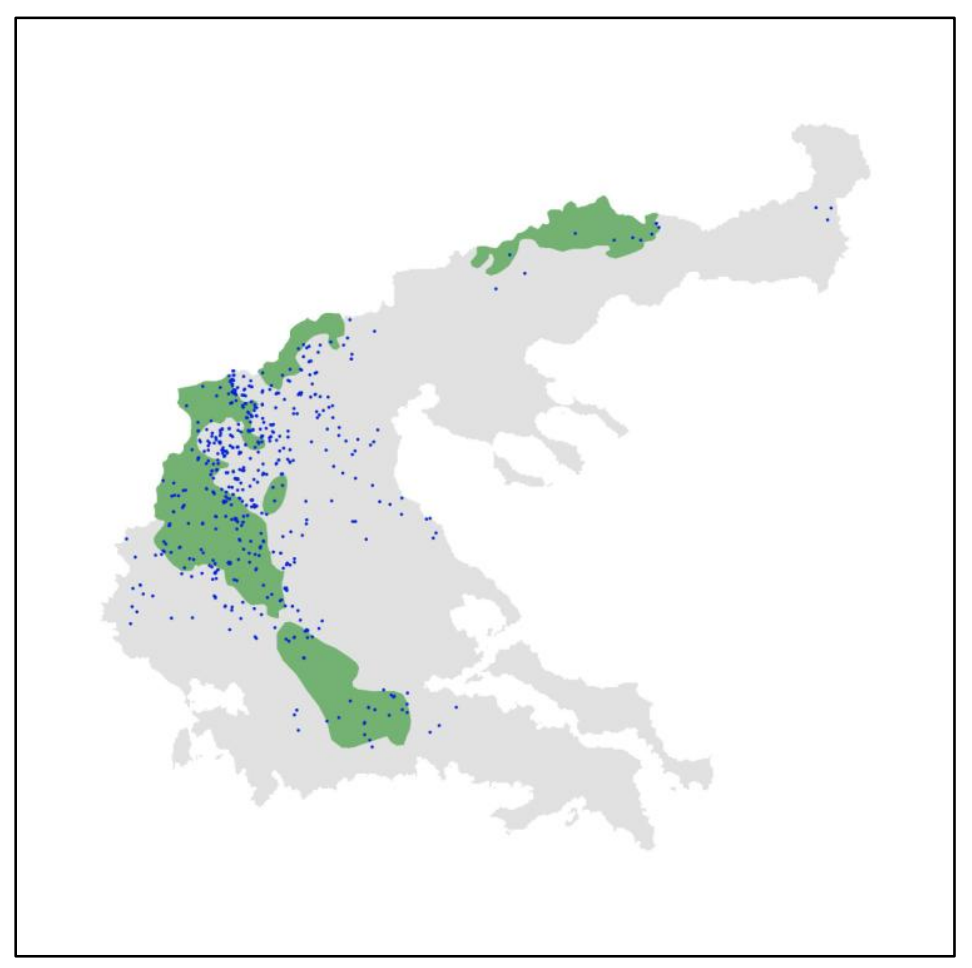

2 Figure 1 Map of a part of continental Greece indicating the distribution of brown bears in the 3 country according to Mertzanis et al. 2009 (shaded green area) and the locations of 632

4 brown bear occurrences recorded through the HBBRIN (2004-2016).

6 Table 1 Habitat characteristics of the past and new distribution of brown bears in Greece (for 7 more information, see the "Studying brown bear presence in Greece" in the Materials and 8 methods section).

\begin{tabular}{lcc} 
& Past distribution & New distribution* \\
\hline Total area $\left(\mathrm{km}^{2}\right)$ & 13,903 & 16,661 \\
Elevation (m.a.s.l.) & 1134.3 & 726.8 \\
Population density (persons/ $\mathrm{km}^{2}$ ) & 32.7 & 39.2 \\
Primary roads $\left(\mathrm{km} / 100 \mathrm{~km}^{2}\right.$ ) & 3.4 & 9.7 \\
Secondary roads $\left(\mathrm{km} / 100 \mathrm{~km}^{2}\right)$ & 41.4 & 87.7 \\
Mature forest $(\%)$ & $51.4 \%$ & $23.8 \%$ \\
Transitional woodland and shrubs & & \\
(\%) & $25.6 \%$ & $25.5 \%$ \\
Grasslands and pastures $(\%)$ & $10.3 \%$ & $12.8 \%$ \\
Agricultural areas (\%) & $10.9 \%$ & $33.4 \%$
\end{tabular}

*Calculations excluding past distribution area

\section{$9 \quad$ Habitat suitability for brown bears in Greece}

The intensity of the PPM was the highest for intermediate altitudes, slopes and percentage of agricultural land (Fig. 2; Appendix 1, Table S2). The intensity of the PPM decreased for 

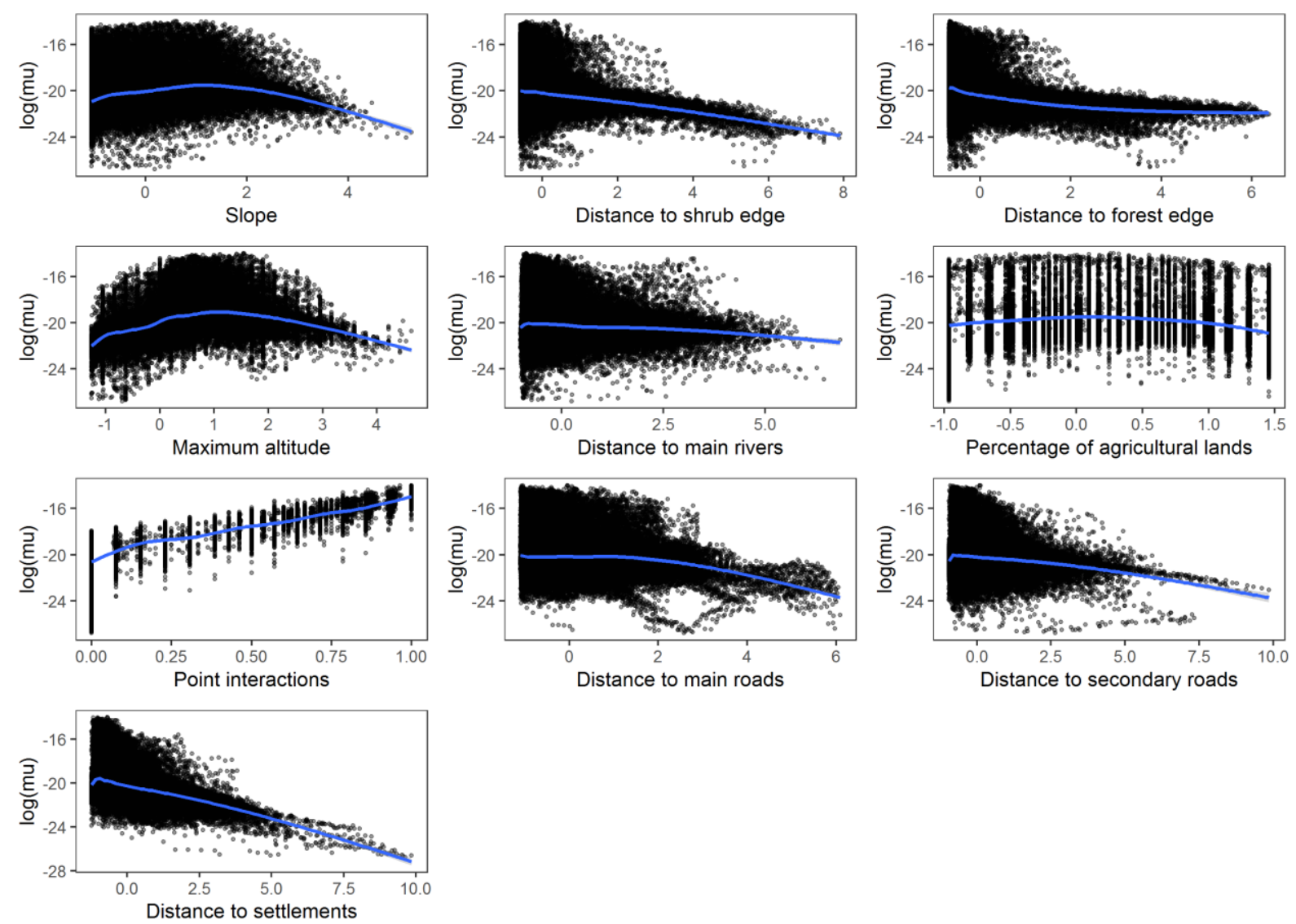

Distance to secondary roads

4 Figure 2 Response curves for each variable in the model. Points: scatterplot of predicted

5 intensity $(\log (\mathrm{mu}))$ against standardised covariate values (mean 0 , variance 1 ). Blue line:

6 fitted smooths (using generalised additive models).

7

8 When examining the predictions from the model (Fig. 3), habitat suitability was patchier

9 when correcting for observer bias (Fig. 3A: best model, correcting for observer bias) than

10 when observer bias was ignored (Fig. 3B: only ecological variables were used). 


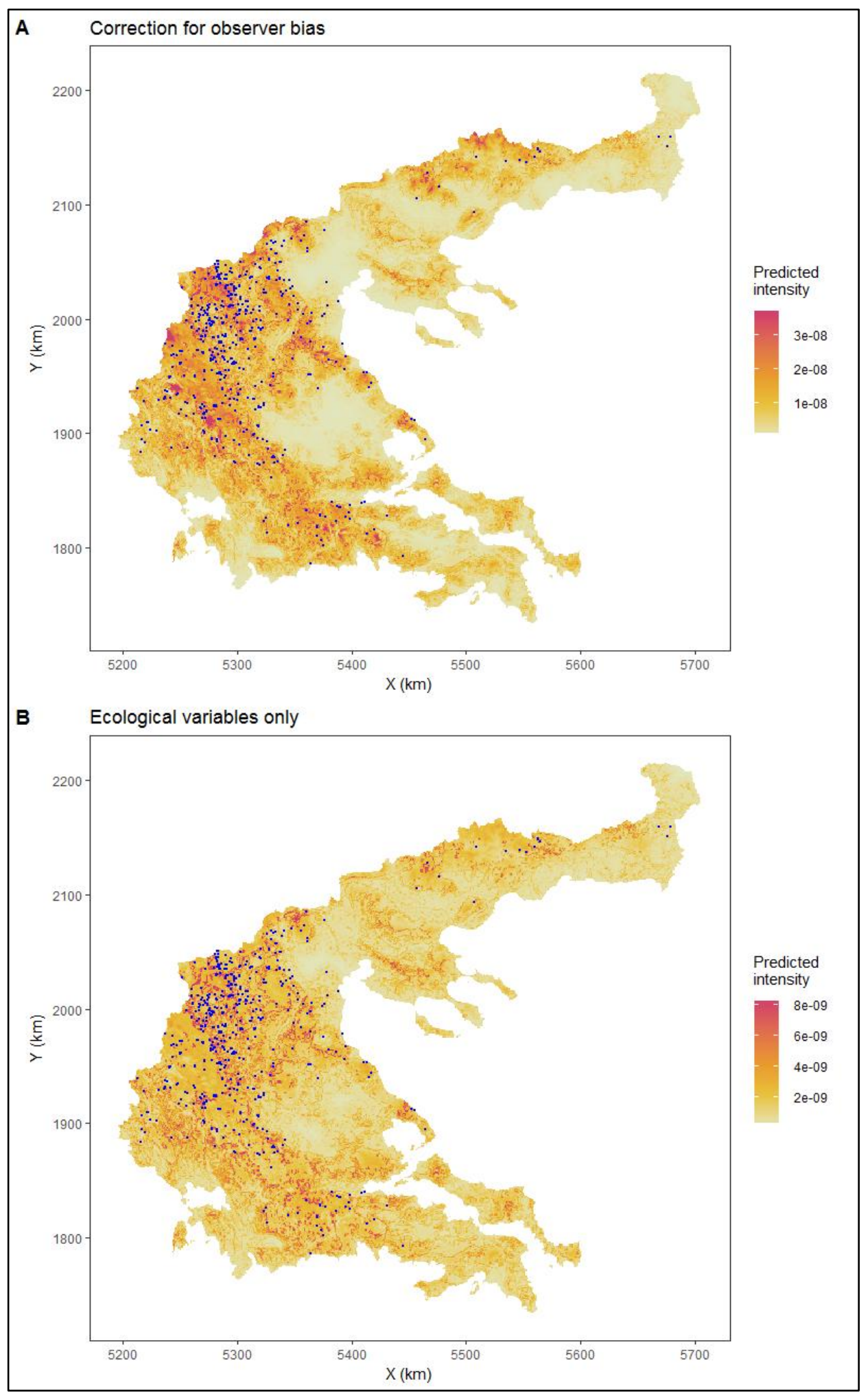

Figure 3 Habitat suitability map from the model with point interaction, A: from the model with both ecological and observer bias variables, where predictions were conditioned on a

4 common level of bias; B: from the model that did not correct for observer bias (i.e. with the

5 ecological variables only); blue points are the opportunistic observations. For visualisation

6 purposes, values above the 0.95 percentile of the global map are set to the 0.95 percentile

7 value.

8

9 Identifying new priority areas for brown bear conservation in Greece

10 Our habitat suitability analysis identified 99 N2K sites with highly suitable brown bear habitat

11 in Greece (i.e. predicted intensities higher than the $80 \%$ quantile covering more than $5 \%$ of 12 the total area of an N2K site) (Fig. 4). Eleven N2K sites contained $>80 \%$ of highly suitable 
habitat, 25 contained $>60 \%$, 53 contained $>40 \%$, while the remaining N2K sites contained <

$240 \%$ of suitable brown bear habitat respectively (Appendix S2, Table N2K). Out of the N2K

3 sites with suitable bear habitat in Greece, 33 had bears included in their SDFs, 66 did not.

$4 \quad$ N2K sites with bears in their SDFs were associated with high-quality bear habitat (88\% of

5 these sites had $>40 \%$ suitable bear habitat) and actual bear presence (in $64 \%$ of these sites,

681 cases of bear presence were recorded). N2K areas without bears in their SDFs were

7 associated with low-quality bear habitat (36\% of these sites had $>40 \%$ suitable bear habitat)

8 and low bear presence (in $45 \%$ of these sites, 104 cases of bear presence were recorded).

9 There were however notable exceptions, including 7 areas (10.6\%) with high quality bear

habitat (i.e. $>60 \%$ ) and bear presence, as well as 5 areas (7.6\%) with low quality bear habitat (i.e. < 20\%) and bear presence (Appendix S2, Table N2K). In addition, bear presence was recorded 485 times in areas not included at all in the N2K network (Fig. 4), mainly in the western population nucleus of the species in the country. High-suitability habitat in this part of the range of the species was located mainly in the area enclosed by the Grammos, VitsiVarnoundas and Askio mountains (Fig. 4).

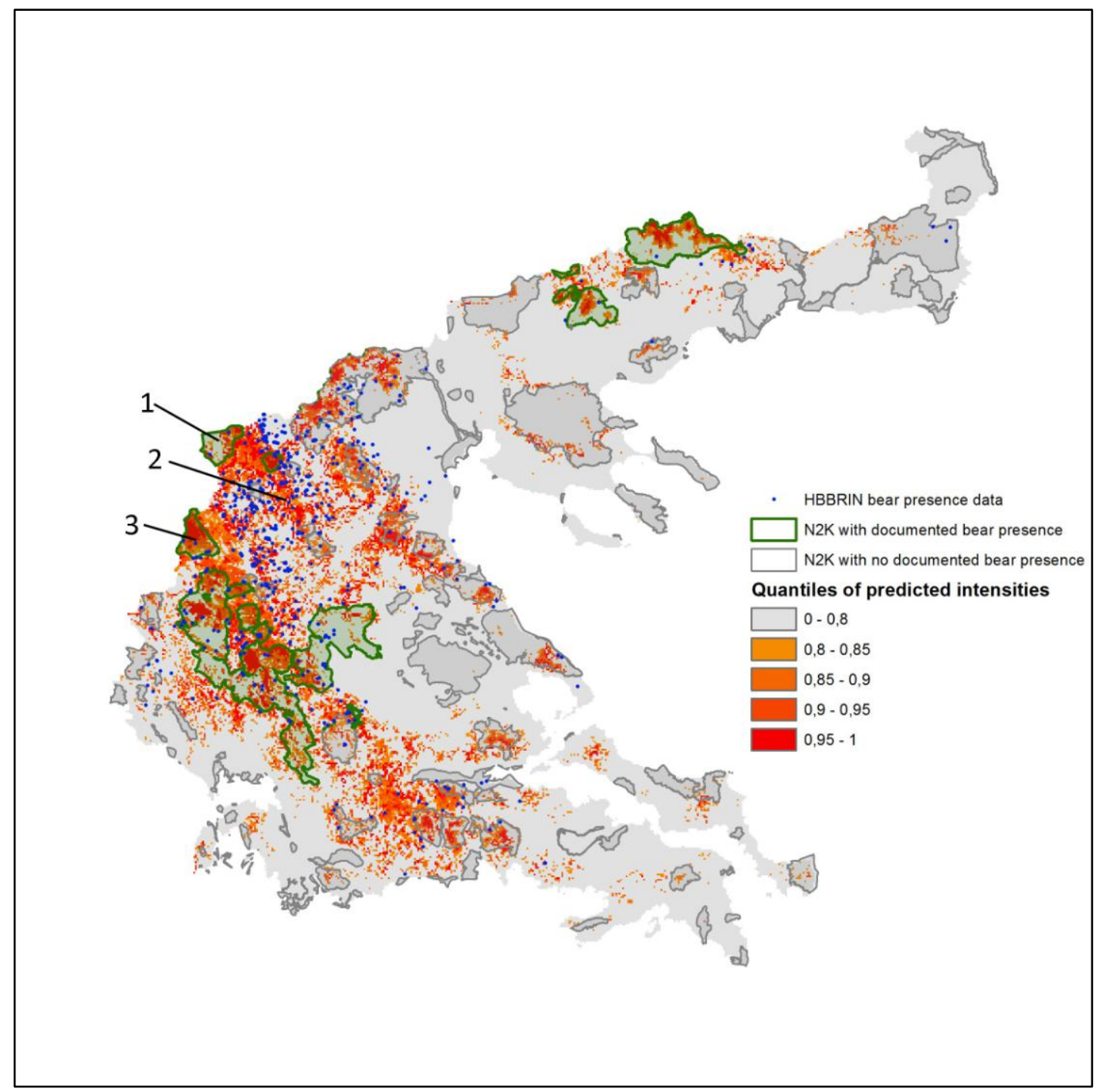

Figure 4 Map of a part of continental Greece indicating the opportunistic data (blue), the predicted highly suitable habitat (red gradient) and the Natura 2000 (N2K) coverage, with 
1 (green) and without presence of bears (gray) in SDFs. Habitat suitability predictions were

2 obtained with the model with point interactions, built with both ecological and observer bias

3 variables, and projected conditioning on a common level of bias. All grid cells for which

4 predicted intensity was above the 0.80 percentile of the global map qualified as highly

5 suitable habitat. Numbers indicate the Mountains: 1) Vitsi-Varnoundas, 2) Askio, and 3)

6 Grammos, respectively.

\section{Discussion}

8

Understanding the processes associated with population recoveries and identifying areas that are suitable for recolonization by endangered species is essential to support effective conservation policies (Cianfrani et al., 2010). We used data from a citizen science project and habitat suitability modelling to understand the spatial aspects associated with the demographic and genetic recovery of an endangered brown bear population at the southern edge of its European distribution and to identify priority areas for conservation.

Brown bear presence during the demographic and genetic recovery of the species in Greece was recorded in both the northeastern and northwestern nuclei of the species in the country. However, a significant percentage of the bear records of the study fell outside of the past distribution of the species in Greece, confirming previous circumstantial evidence (Karamanlidis et al., 2008) and providing for the first time a clear indication of the spatial recovery of the species and the recolonization of new areas. This spatial recovery has been associated primarily with the recolonization of anthropogenic/cultural landscapes (Table 1) and is consistent with the increase in human-bear conflicts (Karamanlidis et al., 2011) and in bear-vehicle collisions (Karamanlidis et al., 2012) recorded in Greece during this time. It is also consistent with our understanding of the genetic recovery of the species in the country (Karamanlidis et al., 2018) and our understanding of the effects of human activity on the activity and habitat selection patterns of brown bears in Greece (de Gabriel Hernando et al. In Review). Although distribution data from the HBBRIN should be viewed with caution, as this is a citizen science project based in the western part of Greece (and therefore more popular in this part of the country), mainly related to the provision of expertise assistance in human-bear conflicts and cases of bears in distress, evidence suggests that bears in Greece in the last 15 years may have increased their range by as much as $100 \%$. Further research is 
necessary to substantiate this fact and complete our understanding of the spatial recovery of

2 this large carnivore in Greece.

The results of the study indicate that bear habitat suitability decreased with distance from forest and shrubland edge (Fig. 2). We interpret the first effect as forest and shrubland edges providing an interface between potential resources outside and refuges inside. Forest cover

6 in itself (which can be interpreted as providing refuge) has already been shown to be an 7 important variable influencing bear presence (Naves et al., 2003, Martin et al., 2012). The 8 quadratic effects found for altitude (consistent with Güthlin et al., 2011), slope and 9 percentage of agricultural land could be also due to the interface between refuge (i.e. higher altitude, steeper slopes and fewer open spaces) and potential resources (i.e. lower altitudes, smooth terrain and existence of crop fields).

Although previous studies have tried to correct for some of the spatial sampling bias inherent to citizen science data (e.g. Phillips et al., 2009), these approaches would not have

been suitable for our case study. For example, volunteers often record within a given study area several other species, usually more common than the focus species, providing information that can be used to infer observer bias and correct for it (e.g. Phillips et al., 2009). However, this approach merely replaces observer bias with species richness bias (Warton et al., 2013), because there might be spatial patterns in the distribution of species richness. Also, this approach would not be applicable to our data collection scheme, as observers spontaneously report bear presence and are unlikely to record the presence of other species. Finally, in cases where, like in our study, citizens spontaneously report opportunistic data, it is almost impossible to rely on any type of information other than the location of the observations. By relying on independently collected data to model observer bias, the method proposed by Warton et al. (2013) has the advantage to provide a flexible and generic way of correcting for observer bias.

However, several issues arise when trying to model observer bias using this approach. First, one needs to select variables that capture observer bias. In doing so, some variables seem intuitive, like those related to human population density or to accessibility of the area. But others can be harder to classify, like, for example, distance to human settlements, which may have a negative effect on species detection with the less people in remote areas, the less likely that someone will detect the species if it is present. Therefore, it seems plausible 
1 to consider distance from human settlements as an observer bias variable. This is likely to be

2 the case for plants, but for free-ranging mammals with large home ranges, the same variable

3 can also have two opposite ecological effects, with bears either avoiding populated areas

4 (e.g. Naves et al., 2003, Martin et al., 2012, Piédallu et al., 2017) because they are perceived

5 as risky, or being attracted to them, as they can provide shelter and/or resources (Elfström et

6 al., 2014). Such difficulty of classifying variables can create limitations because if some

7 features appear both in the ecological and in the observation process, the model is non-

8 identifiable (Fithian \& Hastie, 2013). Similar problems of joint effects on presence and

9 detectability can arise with roads, which can provide access for observers to the sites where

10 bears are present (observer bias variable), but can also be related to disturbance (habitat

11 fragmentation, road mortality) and thus negatively influence the presence of bears (Graves et al., 2011, Martin et al., 2012). We chose to consider the distance to roads as an observer bias variable. Although its negative effect on bear detection (i.e. the further away from a road, the less likely a bear observation will be made) is consistent with that choice, the difficulty to decide a priori whether a variable should be considered as observer or ecological bias emphasizes the need for future research.

Ideally, one should validate the approach - at least for a subset of the study area - using data collected by standardised protocols (hence not suffering from observer bias). This would allow concluding whether the correction for observer bias improved the predictions or not, and would also allow for a model which includes both presence-only and presenceabsence data. However, in this study we did not have access to such good-quality validation data. We had access to telemetry data [Very High Frequency (VHF) and Global Positioning System (GPS) data] - which are commonly available for a subset of the study area in many reasons. First, telemetry data are biased towards the capture locations - it is impossible to 
1 al.'s method (2013) models Johnson's first order selection ("the selection of physical or

2 geographical range of a species"), while using telemetry data would allow us to model third

3 order selection ("the usage made of various habitat components within the home range";

4 Johnson, 1980). In particular, modelling selection within the range does not inform on which

5 environmental conditions are highly unsuitable for the species (by definition, no telemetry

6 data will come from these areas), whereas this distinction between suitable and unsuitable

7 conditions is what is the most important for conservation. This distinction is also where the

8 strength of our predictions lies (i.e. identifying areas that are highly suitable vs. areas that

9 are not - whereas areas with mixed predictions are less useful). Overall, despite the fact that

10 it was not possible to formally validate our correction for observer bias, studies that have had access to good validation datasets have already demonstrated the added value of correcting for observer bias using the approach we used here (e.g. Warton et al., 2013). This is supported in our study also by the findings presented in Fig. 4 (i.e. comparison between our predictions and N2K sites with known bear presence), which indicate that most sites with known presence of bears are predicted as containing highly suitable habitat. Apart from being generally applicable to species that are rare and sampled by citizen science and for which there are only presence-only data, our use of Warton et al.'s method (2013), is of important, practical relevance for (endangered) species conservation in general and brown bear conservation in Greece in particular.

Our habitat suitability modelling produced a map with the predictions of the most suitable bear habitat in the country. The predictions seem less accurate in the northeastern nucleus where a high percentage of observations fall outside areas with high predicted intensities. This could be due to the existence of ecological differences between the Pindos modelling came from the latter area, thus predicting less accurately habitat suitability in that 
1 Greece. However, despite the fact that core bear areas in Greece contain critical habitat for

2 the species, our study recorded a relatively low number (12.3\%) of bear observations in

3 these areas. This discrepancy is likely explained by the increased experience (Galloway et al.,

4 2006) of people living in areas with well-established bear populations, as opposed to people

5 living in areas where bear populations are recovering and bear presence is still an unusual

6 event. This suggests furthermore that our approach might be better suited to identifying

7 priority areas for conservation in areas with recovering wildlife populations, i.e. may be used

8 as an "early-warning" conservation system.

The results of our study indicate furthermore that only a portion of highly suitable habitat

for bears in Greece is currently included in the dedicated N2K network of protected areas for bears; most records of bears originated either from areas with no legal protection status or from protected areas with no specific management measures for the protection of bears, thus creating a new "conservation reality" for the species in the country. On a practical level, this new conservation reality dictates that protected areas that do not have the brown bear in their SDFs, but do have highly suitable habitat and bear presence at the same time in them, will need to prepare for the possibility of the re-establishment of the species in their management area and adjust their management priorities and actions accordingly. For areas with highly suitable habitat and bear presence that are not legally protected, this conservation reality dictates that the information of this study should be used by the national conservation authorities to re-evaluate their national management and conservation priorities, while focusing at the same time in establishing new protected areas 
agricultural activities in the less productive areas as a consequence of the general rural abandonment, allowing a progressive naturalization of these areas (Poyatos et al., 2003).

\section{Conclusions}

For the past several years Greece has suffered a financial crisis that has had a negative effect on the national environmental management apparatus (Lekakis \& Kousis, 2013) that is likely to leave national management authorities in the future struggling to find the necessary funds to effectively monitor and manage biodiversity in the country. Given that the bear population in the country is rapidly recovering (Karamanlidis et al., 2015, Karamanlidis et al., 2018) and that at the same time bear densities and conflicts with humans in Greece are increasing (Karamanlidis et al., 2011), our approach of collecting information on bear presence through a citizen science program and using it to produce habitat suitability maps has been a swift and cheap way of identifying potential hot-spots of bear presence, activity and conflicts with humans in the country, while gaining important insights on the spatial aspects associated with the recovery of this large carnivore.

Our approach will help prioritize conservation actions in the country towards the areas that need it the most and serve as a model approach to other countries facing similar financial and logistic constraints in the monitoring of local biodiversity or facing similar challenges in managing the rapid recovery of a large carnivore. Acknowledging the previous, we propose the intensification of efforts in Greece to further develop the Hellenic Brown Bear Rescue and Information Network, by carrying out targeted awareness campaigns to the general public and selected stakeholders (e.g. Forestry and Veterinary Departments, Management Authorities of Protected areas) that will increase data input and ultimately the quality of the habitat suitability maps produced using this method. At the same time, it is clear that in the case of the brown bear the current setup of the protected areas network in Greece does not reflect the current conservation reality and that there is a clear need to reevaluate the existing network of protected areas in Greece so that it effectively supports the recovery of the species in the country.

\section{References}

Bautista, C., Naves, J., Revilla, E., Fernández, N., Albrecht, J., Scharf, A. K., Rigg, R., Karamanlidis, A. A., Jerina, K., Huber, D., Palazón, S., Kont, R., Ciucci, P., Groff, C., Dutsov, A., Seijas, J., Quenette, P.-I., Olszanska, A., Shkvyria, M., Adamec, M., Ozolins, J., 
Jonozovic, M. \& Selva, N. (2016). Patterns and correlates of claims for brown bear damage on a continental scale. J. Appl. Ecol. 54, 282-292. doi: 10.1111/1365-2664.12708

Center for International Earth Science Information Network (CIESIN) \& Centro Internacional de Agricultura Tropical (CIAT) (2005). Gridded Population of the World, Version 3 (GPWv3) Data Collection.). Palisades, NY: CIESIN, Columbia University.

Chapron, G., Kaczensky, P., Linnell, J. D. C., von Arx, M., Huber, D., Andrén, H., López-Bao, J. V., Adamec, M., Álvares, F., Anders, O., Balčiauskas, L., Balys, V., Bedő, P., Bego, F., Carlos Blanco, J. C., Breitenmoser, U., Brøseth, H., Bufka, L., Bunikyte, R., Ciucci, P., Dutsov, A., Engleder, T., Fuxjäger, C., Groff, G., Holmala, K., Hoxha, B., Iliopoulos, Y., Ionescu, O., Jeremić, J., Jerina, K., Kluth, G., Knauer, F., Kojola, I., Kos, I., Krofel, M., Kubala, J., Kunovac, S., Kusak, J., Kutal, M., Liberg, O., Majić, A., Männil, P., Manz, R., Marboutin, E., Marucco, F., Melovski, D., Mersini, K., Mertzanis, Y., Mysłajek, R. W., Nowak, S., Odden, J., Ozolins, J., Palomero, G., Paunović, M., Persson, J., Potočnik, H., Quenette, P.-Y., Rauer, G., Reinhardt, I., Rigg, R., Ryser, A., Salvatori, V., Skrbinšek, T., Stojanov, A., Swenson, J. E., Szemethy, L., Trajçe, A., Tsingarska-Sedefcheva, E., Váňa, M., Veeroja, R., Wabakken, P., Wölfl, M., Wölfl, S., Zimmermann, F., Zlatanova, D. \& Boitani, I. (2014). Recovery of large carnivores in Europe's modern human-dominated landscapes. Science 346, 1517-1519. doi: 10.1126/science.1257553

Cianfrani, C., Le Lay, G., Hirzel, A. H. \& Loy, A. (2010). Do habitat suitability models reliably predict the recovery areas of threatened species? J. Appl. Ecol. 47, 421-430. doi: https://doi.org/10.1111/j.1365-2664.2010.01781.x

Daru, B. H., Park, D. S., Primack, R. B., Willis, C. G., Barrington, D. S., Whitfeld, T. J. S., Seidler, T. G., Sweeney, P. W., Foster, D. R., Ellison, A. M. \& Davis, C. C. (2018). Widespread sampling biases in herbaria revealed from large-scale digitization. New Phyt. 217, 939955. doi: https://doi.org/10.1111/nph.14855

Di Minin, E., Slotow, R., Hunter, L. T., Pouzols, F. M., Toivonen, T., Verburg, P. H., LeaderWilliams, N., Petracca, L. \& Moilanen, A. (2016). Global priorities for national carnivore conservation under land use change. Sci. Rep. 6, 23814. doi: https://doi.org/10.1038/srep23814 
Dickinson, J. L., Zuckerberg, B. \& Bonter, D. N. (2010). Citizen science as an ecological research tool: challenges and benefits. Ann. Rev. Ecol., Evol, and Syst. 41, 149-172. doi: https://doi.org/10.1146/annurev-ecolsys-102209-144636

Dickinson, J. L., Shirk, J., Bonter, D., Bonney, R., Crain, R. L., Martin, J., Phillips, T. \& Purcell, K. (2012). The current state of citizen science as a tool for ecological research and public engagement. Front. Ecol. Environ. 10, 291-297. doi: https://doi.org/10.1890/110236

Elfström, M., Davey, M. L., Zedrosser, A., Müller, M., De Barba, M., Støen, O. G., Miquel, C., Taberlet, P., Hackländer, K. \& Swenson, J. E. (2014). Do Scandinavian brown bears approach settlements to obtain high-quality food? Biol. Cons. 178, 128-135. doi: https://doi.org/10.1016/j.biocon.2014.08.003

Fithian, W. \& Hastie, T. (2013). Finite-sample equivalence in statistical models for presenceonly data. Ann. Appl. Stat. 7, 1917. doi: 10.1214/13-AOAS667

Galloway, A. W. E., Tudor, M. T. \& Vander Haegen, M. (2006). The reliability of citizen science: a case study of Oregon white oak stand surveys. Wildl. Soc. Bull. 34, 1425-1429. doi: https://doi.org/10.2193/0091-7648(2006)34[1425:TROCSA]2.0.CO;2

Geldmann, J., Heilmann-Clausen, J., Holm, T. E., Levinsky, I., Markussen, B., Olsen, K., Rahbek, C. \& Tøttrup, A. P. (2016). What determines spatial bias in citizen science? Exploring four recording schemes with different proficiency requirements. Divers. \& Distr. 22, 1139-1149. doi: https://doi.org/10.1111/ddi.12477

Graves, T. A., Kendall, K. C., Royle, J. A., Stetz, J. B. \& Macleod, A. C. (2011). Linking landscape characteristics to local grizzly bear abundance using multiple detection methods in a hierarchical model. Anim. Cons. 14, 652-664. doi: https://doi.org/10.1111/j.14691795.2011.00471.x

Güthlin, D., Knauer, F., Kneib, T., Küchenhoff, H., Kaczensky, P., Rauer, G., Jonozovič, M., Mustoni, A. \& Jerina, K. (2011). Estimating habitat suitability and potential population size for brown bears in the Eastern Alps. Biol. Cons. 144, 1733-1741. doi: https://doi.org/10.1016/j.biocon.2011.03.010

Guisan, A., Thuiller, W. \& Zimmermann, N.E. (2017). Habitat suitability and distribution models. With applications in R. Cambridge: Cambridge University Press. https://doi.org/10.1017/9781139028271 
Hortal, J., Jiménez-Valverde, A., Gómez, J. F., Lobo, J. M. \& Baselga, A. (2008). Historical bias in biodiversity inventories affects the observed environmental niche of the species. Oikos 117, 847-858. doi: https://doi.org/10.1111/j.0030-1299.2008.16434.x

Johnson, D. H. (1980). The comparison of usage and availability measurements for evaluating resource preference. Ecology 61, 65-71. doi: https://doi.org/10.2307/1937156

Karamanlidis, A. A., Krambokoukis, L. \& Kantiros, D. (2008). Challenges and problems arising from the range expansion of brown bears in Greece. International Bear News 17, 17.

Karamanlidis, A. A., Sanopoulos, A., Georgiadis, L. \& Zedrosser, A. (2011). Structural and economic aspects of human-bear conflicts in Greece. Ursus 22, 141-151. doi: http://dx.doi.org/10.2192/URSUS-D-10-00016.1

Karamanlidis, A. A., Beecham, J., Bousbouras, D., de Gabriel Hernando, M., Evangelou, C., Georgiadis, L., Grivas, K., Krambokoukis, L., Panagiotopoulos, N. \& Papakostas, G. (2012). Bear - vehicle collisions: a holistic approach to evaluating and mitigating the effects of this new conservation threat to brown bears in Greece. In: 21st International Conference on Bear Research and Management. New Delhi, India.

Karamanlidis, A. A., de Gabriel Hernando, M., Krambokoukis, L. \& Gimenez, O. (2015). Evidence of a large carnivore population recovery: counting bears in Greece. J. Nat. Cons. 27, 10-17. doi: https://doi.org/10.1016/j.jnc.2015.06.002

Karamanlidis, A. A., Skrbinšek, T., de Gabriel Hernando, M., Krambokoukis, L., MunozFuentes, V., Bailey, Z., Nowak, C. \& Stronen, A. V. (2018). History-driven population structure and assymetric gene flow in a recovering large carnivore at the rear-edge of its European range. Heredity 120, 168-182. doi: https://doi.org/10.1038/s41437-017-0031-4

Kindberg, J., Ericsson, G. \& Swenson, J. E. (2009). Monitoring rare or elusive large mammals using effort-corrected voluntary observers. Biol. Cons. 142, 159-165. doi: https://doi.org/10.1016/j.biocon.2008.10.009

Kojola, I., Aspi, J., Hakala, A., Heikkinen, S., Ilmoni, C. \& Ronkainen, S. (2006). Dispersal in an expanding wolf population in Finland. J. Mamm. 87, 281-286. doi: https://doi.org/10.1644/05-MAMM-A-061R2.1

Lekakis, J. N. \& Kousis, M. (2013). Economic crisis, Troika and the environment in Greece. South Eur. Soc. \& Pol. 18, 305-331. doi: https://doi.org/10.1080/13608746.2013.799731 
Linnell, J., Salvatori, V. \& Boitani, L. (2008). Guidelines for population level management plans for large carnivores in Europe. 1-78.

López-Bao, J. V., Kaczensky, P., Linnell, J. D. C., Boitani, L. \& Chapron, G. (2015). Carnivore coexistence: Wilderness not required. Science 348, 871-872. doi: 10.1126/science.348.6237.871-b

Martin, J., Revilla, E., Quenette, P. Y., Naves, J., Allaine, D. \& Swenson, J. E. (2012). Brown bear habitat suitability in the Pyrenees: transferability across sites and linking scales to make the most of scarce data. J. Appl. Ecol. 49, 621-631. doi: https://doi.org/10.1111/j.1365-2664.2012.02139.x

Martin, J., van Moorter, B., Revilla, E., Blanchard, P., Dray, S., Quenette, P. Y., Allainé, D. \& Swenson, J. E. (2013). Reciprocal modulation of internal and external factors determines individual movements. J. Anim. Ecol. 82, 290-300. doi: https://doi.org/10.1111/j.13652656.2012.02038.x

Mertzanis, G., Giannakopoulos, A. \& Pylidis, C. (2009). Ursus arctos (Linnaeus, 1758). In: Red Data Book of the Threatened Animal Species of Greece: 387-389. Legakis, A. , Maragou, P. (Eds.). Athens: Hellenic Zoological Society.

Naves, J., Wiegand, T., Revilla, E. \& Delibes, M. (2003). Endangered species constrained by natural and human factors: the case of brown bears in northern Spain. Cons. Biol. 17, 1276-1289. doi: https://doi.org/10.1046/j.1523-1739.2003.02144.x

Newsome, T. M. \& Ripple, W. J. (2015). Carnivore coexistence: trophic cascades. Science 347, 383. doi: 10.1126/science.347.6220.383-a

Ordiz, A., Kindberg, J., Saebo, S., Swenson, J. E. \& Stoen, O. G. (2014). Brown bear circadian behavior reveals human environmental encroachment. Biol. Cons. 173, 1-9. doi: https://doi.org/10.1016/j.biocon.2014.03.006

Phillips, S. J., Dudík, M., Elith, J., Graham, C. H., Lehmann, A., Leathwick, J. \& Ferrier, S. (2009). Sample selection bias and presence-only distribution models: implications for background and pseudo-absence data. Ecol. Appl. 19, 181-197. doi: https://doi.org/10.1890/07-2153.1

Piédallu, B., Quenette, P. Y., Bombillon, N., Gastineau, A., Miquel, C. \& Gimenez, O. (2017). Determinants and patterns of the endangered brown bear Ursus arctos habitat use in the 
French Pyrenees revealed by occupancy modeling. Oryx, 075895. doi: https://doi.org/10.1101/075895

Poyatos, R., Latron, J. \& Llorens, P. (2003). Land use and land cover change after agricultural abandonment: the case of a Mediterranean mountain area (Catalan Pre-Pyrenees). Moun. Res. \& Devel. 23, 362-368. doi: https://doi.org/10.1659/02764741(2003)023[0362:LUALCC]2.0.CO;2

QGIS Development Team (2016). Quantum geographic information system.

Quantum GIS Development Team (2013). Quantum GIS Geographic Information System: Open Source Geospatial Foundation Project.

R Development Core Team (2011). R: A language and environment for statistical computing.). Vienna, Austria: R Foundation for Statistical Computing.

Renner, I. W., Elith, J., Baddeley, A., Fithian, W., Hastie, T., Phillips, S. J., Popovic, G. \& Warton, D. I. (2015). Point process models for presence-only analysis. Meth. Ecol. \& Evol. 6, 366-379. doi: 10.1111/2041-210X.12352

Ripple, W. J., Estes, J. A., Beschta, R. L., Wilmers, C. C., Ritchie, E. G., Hebblewhite, M., Berger, J., Elmhagen, B., Letnic, M., Nelson, M. P., Schmitz, O. J., Smith, D. W., Wallach, A. D. \& Wirsing, A. J. (2014). Status and ecological effects of the world's largest carnivores. Science 343, 1241484. doi: 10.1126/science.1241484

Signer, J. (2016). rhr: Reproducible home ranges with R. R packages version 1.2.909.

Swenson, J. E. \& Sandegren, F. (2000). Conservation of European brown bear populations: experiences from Scandinavia. In: La conservacion del oso pardo en Europa: un reto de cara al siglo XXI: 111-116. Layna, J. F., Heredia, B., Palomero, G. , Doadrio, I. (Eds.). Madrid.

Treves, A. \& Karanth, K. U. (2003). Human-carnivore conflict and perspectives on carnivore management worldwide. Cons. Biol. 17, 1491-1499. doi: https://doi.org/10.1111/j.15231739.2003.00059.x

van Strien, A. J., van Swaay, C. A. \& Termaat, T. (2013). Opportunistic citizen science data of animal species produce reliable estimates of distribution trends if analysed with occupancy models. J. Appl. Ecol. 50, 1450-1458. doi: https://doi.org/10.1111/13652664.12158 
Votsi, N. E. P., Zomeni, M. S. \& Pantis, J. D. (2016). Evaluating the effectiveness of Natura 2000 Network for wolf conservation: A case-study in Greece. Environ. Manag. 57, 257270. doi: $10.1007 / s 00267-015-0621-y$

Warton, D. I., Renner, I. W. \& Ramp, D. (2013). Model-based control of observer bias for the analysis of presence-only data in ecology. PloS One 8, e79168. doi: https://doi.org/10.1371/journal.pone.0079168

7 Data Accessibility Statement

8 All data and codes used to carry out the analyses and generate the maps are provided as $9 \quad$ Supplementary Material (Appendix 3).

Additional Supporting Information may be found in the online version of this article:

Appendix S1: Details on the methods

(Bear_spxy2017.csv); Habitat data (Table N2K)

Appendix S3: R Code of the study 